BODA György

\title{
HATÉKONY VÁLLALAT, HATÉKONY TÁRSADALOM
}

\begin{abstract}
Lehet-e a társadalomban kibontakozó konfliktusoktól vállalati keretek között megszabadulni? Mivel a vállalat termelési függvénye túlmutat a vállalat határain, ez illúzió, és az igazi vállalati hatékonyság csak a társadalmi folyamatok hatékonyabbá tételével alakulhat ki.
\end{abstract}

\section{Kulcsszavak: termelési függvény, tốkemodell, beruházási hányad, nem anyagi tốke}

Ha a társadalmi hatékonysággal baj van, akkor felerôsödik az egyéni megoldások szerepe. Nem hatékony környezettôl mindenki szabadulni igyekszik. Kérdés, meddig lehetünk sikeresek, ha erre törekszünk? Lehet-e egy vállalat hatékony egy nem hatékony társadalomban? Mi az összefüggés a vállalati hatékonyság és az ôt körülvevő környezet hatékonysága között?

Ma Magyarországon a társadalmi hatékonyságba vetett hit megingott. Húsz év telt el a rendszerváltás óta és a kialakult magyar kapitalizmus eddig nem váltotta be a hozzá füzött reményeket, sốt több lényeges ponton a megvalósult magyarországi szocializmus teljesítményét sem tudta felülmúlni. ${ }^{1}$ Megingott az állam hatékonyabb múködésébe vetett bizalom. Egyelőre egyre kisebb esélyét látni annak, hogy a jelenlegi elit az államot hatékonyabbá tudja tenni. Mindemellett felerősödik a gyanú, hogy az állami tisztviselók tehetetlensége lassan a megélhetési tevékenység és a „kaparj magadnak” korrupciós irányba fordul. Nő a félelem, hogy egy ilyen államhatalom nem tud rendet teremteni a gazdaságban sem, ahol a törvénytelenségek súlya, és ezzel a feketegazdaság szerepe felerősödik. Ilyen körülmények között jogos az egyéni megoldások keresése.

Nagy kérdés, hogy az egyéni megoldások sikerre vezethetnek-e! A válaszhoz elóbb azt kell tisztázni, hogy léteznek-e olyan vállalati határok, melyek mögött a hatékonyságot a vállalati vezetés önálló törekvéseként maximalizálni lehet, és így meg lehet-e szabadulni a nem hatékony környezet negatív és bénító hatásaitól. Ha ilyen határok vannak, akkor az egyéni megoldások ideig-óráig eredményesek lehetnek. Ha nincsenek, akkor csak túlélést, legfeljebb átmeneti és taktikai eredményeket remélhetünk tőlük. Stratégiai áttörést nem.

\section{A vállalat határai}

A vállalat határait a vállalat termelési függvénye alapján kívánjuk értelmezni. A határ tehát nem azonos a vállalat kerítésével. A bankban vezetett folyószámlát szintén a vállalat részének tekintjük, noha a vállalat kerítésén kívül van. Több munkavállaló dolgozhat tartósan a vállalat kerítésén kívül (kiküldetés, ügynöki munka, otthon dolgozás stb.), de azért ớk a vállalat részét képezik. A vállalat határain belülinek tehát elsôsorban a vállalat által tulajdonolt termelési tényezóket értjük, függetlenül azok fizikai helyétól.

Be kívánjuk bizonyítani, hogy olyan termelési tényezô kombináció nem létezik, amely minden elemében a vállalat által tulajdonolható, azaz a vállalat határain belül van. Ezért a vállalati hatékonyság nem kizárólagosan a vállalati akarat függvénye. Az jelentôs részben függ a vállalat által nem tulajdonolt, és így a vállalat határain kívüli termelési tényezôk hatékonyságától.

\section{A vállalat termelési függvénye}

De hogyan néz ki a vállalat termelési függvénye? Ehhez induljunk ki a termelési függvények általános alakjából. Ez az alaptankönyvek ${ }^{2}$ szerint

$$
Y=F(K, L)
$$

ahol $Y$ a kibocsátás, a $K$ tốke és az $L$ munka függvénye. Természetesnek túnik az a gondolat, hogy a vállalati kibocsátás is a vállalat által lekötött tớke és a vállalat által alkalmazott munka függvénye, így a vállalati termelési függvény is ugyanígy néz ki. 
Az 1. alatti függvényben a munka nem a vállalaté A vállalat határait tehát csak a tóke alapján értelmezhetjük. Kérdésünk tehát így módosul: létezik-e olya tốke, amely kizárólagosan a vállalaté?

A gondolkodást számokkal is alá kívánjuk támasztani. Ezért az 1. helyett annak precízebb matematik alakjával, a Cobb-Douglas termelés függvénnyel dolgozunk ${ }^{3}$ és azt a Richter Rt.-re számszerúsítjük is. Ekkor termelési függvényünk a következő́képpen néz ki:

$Y=A K^{\alpha} L^{\beta}$

2)

ahol $Y=$ a kibocsátás

$K=$ a kibocsátás érdekében lekötött anyagi tóke,

$L=$ a létszám,

$a=\mathrm{a}$ tóke részesedése a megtermelt $\mathrm{ki}-$ bocsátásból,

$\beta=1-\alpha=a$ munka részesedése a megtermelt kibocsátásból és

$A=$ az együttes tényezôhatékonyságot és

az egyéb tényezóket számszerúsítő technikai paraméter.

A tóke tartalmára vonatkozóan Varian (2004) tókefogalmából indulunk ki"

„A termelési ráfordításokat termelési tényezőknek

(factors of production) hívjuk. A termelési tényezóket

gyakran olyan tág kategóriákba soroljuk, mint a föld

a munkaerô, a tôke és a nyersanyagok. Az teljesen

nyilvánvaló, mit is jelent a föld, a munkaeró vagy a

nyersanyag, a tőke viszont új fogalom. Tókejavaknak

(capital goods) hívjuk azokat a termelési ráfordítá-

sokat, amelyek maguk is a termelés során elóállíton

javak. A tókejavak alajjúban véve eszközök vagy gé-

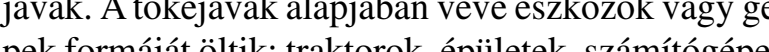

pek for A jejak vagy egyebek. Elôfordu, hogy a toke fogalmát egy uzzleti vallalkozás elkezdescen a vagy fentartásához szükséges pénzösszeg meghatározására használják. Mi erre a fogalomra a pénztóke (financial capita) szót fogjuk használni, és a tőkejószág vagy fizika tôke (physical capital) elnevezéseket a termelésbe elóállított tényezốkre tartjuk fenn."

A 2-es függvényt egy közismert módon átalakítjuk ${ }^{5}$ :

$y=A k^{\alpha}$

Ebben az egyenletben:

Ez nemcsak könnyebben kezelhetô, de a figyelmünet a termelékenységre és tókefelszereltségre irányítja. A termelékenység maga a hatékonyság, amit vizsgáln akarunk. A tókefelszereltség is hatékonyságot fejez ki.

Ha a 3-as összefüggést a Richter Rt. input adataira számszerüsítjük, az 1. ábrán látható eredményt kapjuk.

A munkatermelékenység összetevői

(Richter imputok, $\alpha_{1}$ beruházási hányad)

1. ábra

= az egy fổe jutó kibocsátás $(\mathrm{Y} / \mathrm{L})$

$k=\mathrm{a}$ kibocsátás érdekében az egy létszámegységre jutó lekötött anyagi tóke, saját szóhasználatunkban a fajlagos technikai felszereltség $(\mathrm{K} / \mathrm{L})$,

$\alpha=a$ tóke részesedése a megtermelt kibocsátásból, és

$A=$ az együttes tényezóhatékonyságot és az egyéb ténye-

zóket számszerúsító technikai paraméter.
Eszerint ha a tốkefelszereltséget a Richter vagyonmérlegében kimutatott befektetett eszközök alapján értelmezzük, akkor az a Richter termelékenységnövekedését (az összterület nagyságát) hosszabb idôszak átlagában csak mintegy 25 vagy 30 százalékban magyarázza a tókefelszereltség növekedése (sötét terület). A termelékenység növekedése nagyobb részt a termelési tényezó hatékonyság (TFP) változásának (világos terület) köszönhető. ${ }^{6}$ Ebben a felfogásban minden hatékonyságnövekmény a befektetett eszközök abszolút növekményének, illetve a befektetett eszközök és a munka ekü̈ttes hatékonyságnövekedésének tulajdónthó.

Az eredmény matematikailag korrekt, sajnos azonban azt jelzi, hogy a mögötte lévố termelési függvény közgazdaságilag használhatatlan. Ebben a felfogásban mindent az anyagi és fizikai valóságában mért tóke és létszám hoz létre, miközben a fejlódés az együttes termelékenységet növeli. Emiatt azonban az együttes termelékenység, az úgynevezett Solow reziduális lesz a meghatározó, és ebból nem látjuk, hogy az mely befektetésból jön. Igy egy tautológiához jutunk. A hatékonyság növekedése a hatékonyság növekedésétól függ. Ezzel nem jutunk semmire, különösen akkor, ha azt akarjuk megmondani, hogy mit kell tenni a további hatékonyság növelése érdekében, illetve hova kell beszeretnénk eróforrásainkat felhasználni.

Az eredménnyel kapcsolatos kételyeinket jól illusztrálja a következó hasonlat. Ha van egy autónk és tudunk vezetni, akkor a tókénk és az autóvezetôi munkánk eredményeként körülbelül egy óra alatt megtesszük a Budapest-Jászberény távolságot. Ez esetben ismertek tényezőinputok, a kibocsátás és maga a termelési függvény is. Most tételezzük fel, hogy építenek egy autópályát Jászberényig, s ezzel fél órára csökken az út. Ha termelési függvényünk továbbra is kéttényezős marad akkor a javulást kizárólag az autó és a mi vezetési munkánk együttes tényezóhatékonyság-javulásának kell betudnunk, ami aligha helyes következtetés. A példa termelési függvényébe be kell kapcsolni az infrastruktúrát nálatában már egyébként is ott volt egy olyan termelés tényező formájában, amelyet nem mi fektettünk be és ezért nemcsak mérni felejtettuik el, de arra sem gondoltunk, vajon hatékonyan használjuk-e azt.

Mindezek alapján a következő fontos megállapításokat tehetjük:

- Hatékonyságról csak akkor beszélhetünk, ha mögötte munkáló összes termelési tényezốt azonosítottuk. Ennek hianyában a „nemtudásunkat”

is hatékonyságnak nevezzük.

\section{VEZETÉSTUDOMÁNY}

Minden termelési tényezónek van

egy saját hatékonysága, amennyivel az a kibocsátást növeli ${ }^{7}$, illetve

egy hozzájárulása az együttes tényezóhatékonyság növeléséhez.

- Ha nem azonosítjuk a valós termelési tényezóket, akkor a nem azonosított termelési tényezók saját hatékonyságát belemossuk a termelési tényezók együttes hatékonyságának - a TFP-nek - a változásába, ami a hatékonyság téves értelmezéséhez, túlbecsléséhez vezet.

- A hatékonyságot önmagában nem lehet menedzselni. Azt csak az azt hordozó termelési tényezók menedzsmentjén keresztül lehet növelni.

- Emiatt befektetéseink hibásak lehetnek, hisz csak az azonosított termelési tényezókbe fektetünk be, holott lehet, hogy a nem azonosítottak fejlesztése lenne kívánatos.

A további gondolkodáshoz Theodor Schultz (1983) jta meg a kulcsot, amikor azt tanácsolta, hogy figyeljük a beruházásokat, de azt ne csak szúken, az anyagi szférára értelmezzük, hanem minden beruházási jellegú kiadásra, ami kibocsátást növelô eszközt teremt. ${ }^{8}$

Most Schultz alapján gondoljuk végig, hogy milyen het a valós beruházási hányada és az annak alapjón létrejövó valós tốkeállománya és az annak alapján trejón valós tókeállománya - befektetetteszközGichter. Itt már nem fogunk egy az egyben a Richter adataira támaszkodni, hisz a Schulz-lele gondolathenetbe illeszkedo uj adatok nem âlnak rendelkezésünkre, de azért meg kivánunk maradni a Richter definiálta hatékonysági keretek között. Mostantól tehát nem a Richterrớl lesz szó, hanem egy Richter típusú vállalat modelljéról.

A hagyományos értelmezés szerint a beruházás nem más, mint az új értéknek az a része, amit az anyagi/ tárgyi tókék növelésére fordítunk. A beruházási hányadon általában az új értékbốl az anyagi/tárgyi eszközök fejlesztésére szánt összegek arányát értik.

Hogy a beruházások ilyen leszúkített értelmezése mennire tarthatatan, azt leginkább akkor lájuk, ba

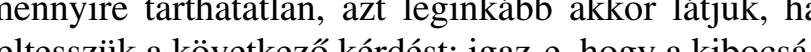
tás 1-a hányadát elfogyasztják? Ez nyilván nonszesá A Richter típusú vállalat bérköltsége akár közterbekkel együtt is jóval kisebb, mint $(1-\alpha) Y$, mivel az uj étćk jelentốs része kisebb, mint $(1-\alpha) Y$, mivel az új érték jelentốs része megy $K+F$-re, és további, fontos nem anyagi, immateriális ${ }^{9}$ kapacitások kialakítására vagy fenntartására. Ezek biztosítják az ügyfélkapcsolatok fejlesztését és megtartását, a szervezettség növelését és megtartását, a képzést stb. ${ }^{10}$ Itt utalunk vissza Ónodi Annamária munkájára (2005), melyben tételesen felsorolja, hogy melyek azok a költségek, ráforditások, 
melyeket mindenképpen aktiválni kellene, ha a vállalat befektetett eszközenek valơs nagyságrendjét meg akarnán ragadni. ${ }^{11}$ Ezek lényegében ugyanazok, melyeket mi is felsoroltunk.

Ráadásul még azt az eretnek feltételezést is végig kell gondolnunk, hogy a munkaköltség mögötti felhasználás jelentôs része is visszaforgatódik az ú érték termelésébe, tehát beruházási jellegú felhasználás lesz. A munkaköltség TB-eleme ugyanúgy szolgálja a munké Tín képesség fentartásá, mint a pihenéshez szórakozáshoz szükséges egészségi álla-

pot biztosítását. Ha a dolgozó magát képezi, megint csak a munkaképességét is növeli. Gyereknevelési kiadás nak jelentôs része is beruházási célunak tekinthetó.

Mindezen megfontolások alapján - ha a készletvátozásoktól eltekintünk - a 2. ábrán látható beruházási hányad változatok értelmezhetók. Eszerint $\alpha_{1}$ a hagyományos értelemben vett anyagi beruházási hányad, új értéknek az a része, amelyet anyagi/tárgyi eszközök növelésére fordítunk. $\alpha_{2}$ a tárgyi és nem tárgyi eszközök együttes növelésére fordított beruházásokat közelíti. Ebbe az anyagi eszközök növelésén túl szerepel minden olyan kiadás, amely az ügyfélkapcsolatokra, a szervezettś́gre és a kompetencia növelésére fordítódik. A terzet-

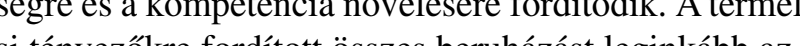
si tenyeź́ beruházási hányad kozeliti, anely az a $a_{2}$ mogotti vállala lési tényezók növelésére fordított beruházásokkal.

lési tényezôk nōvelésére fordított beruházásokkal.
Magasabb beruházási hányad magasabb tôke-, azaz befektetett eszközállományhoz vezet. Ezért nem tehet jük meg azt, hogy a 3-as összefüggésben csak a kitevôt változtatjuk. A beruházási hányad növekedésének együtt kell mozognia a tőkefelszereltség növekedésével is. Ennek nagyságrendjét meg is becsültük. A számításokat a függelék 3-4. táblázataiban közöljük. ${ }^{12}$

A munkatermelékenység összetevôi (trendesített imputok, $\alpha_{2}$ beruházási hányad) tókeelemek jelentốs része nem szakítható el a hordoszempontjából szemléletesen elemzi a különbözó tóketás érdekében lekötött nem anyagi, azaz immateriális tốke.

A 4-es összefüggés Cobb-Douglas típusú változata:

$$
\text { 2. ábra } \quad Y=A_{2} K^{\alpha_{1}} L^{\beta_{2}} I^{\gamma}
$$

Beruházási hányad változatok

\begin{tabular}{|c|c|c|c|c|}
\hline \multirow[b]{2}{*}{$\begin{array}{c}\text { Anyagi } \\
\text { beruhazzások }\end{array}$} & \multirow[b]{2}{*}{$\begin{array}{l}\text { Nem anyagi } \\
\text { beruházások }\end{array}$} & \multicolumn{2}{|c|}{ Munkaköltség } & \multirow[b]{2}{*}{ Összeser } \\
\hline & & \begin{tabular}{|l} 
Munkaképesség \\
rekonstrukciója
\end{tabular} & Valós fogyasztás & \\
\hline$b_{1}$ & $b_{2}$ & $\mathrm{f}_{2}$ & $f_{1}$ & Y \\
\hline$\alpha_{2}=b_{2} / \gamma$ & \multicolumn{3}{|c|}{$\beta_{1}=1-\alpha_{1}$} & 100 \\
\hline \multicolumn{2}{|c|}{$a_{2}=\left(b_{1}+b_{2}\right) / Y$} & \multicolumn{2}{|c|}{$\beta_{2}=1-a_{2}$} & 100 \\
\hline & $\alpha_{3}=\left(b_{1}+b_{2}+f_{2}\right) / N$ & & $\beta_{3}=1-\alpha_{3}$ & 100 \\
\hline
\end{tabular}

ahol $\gamma_{2}=\alpha_{2}-a_{1}$.

Az 5. egyenletben $a_{1}$ továbbra is a korábban használt beruházási hányad, $\beta_{2}$ azonban már az $a_{2}$-nek megfelelő fogyasztási hányad, míg a harmadik termelési tényező kitevője az $a_{2}$ és az $a_{1}$ különbsége. Az A tényező is kapott egy kettes indexet, ami azt jelzi, hogy

Ha az 1. ábrán látható számításokat az $\alpha_{2}$ beruházási $\quad$ az $a_{2}$-es beruházási hányad esetén jelentôsen változik hányaddal és az ahhoz becsült tókével újra számítjuk, akkor a korábbihoz képest fordított eredményre jutunk (lásd a 3. ábrát).
Az 5. egyenlet a 4. ábrán látható egyszerúbb alakra hozható: $^{13}$

$\underset{\substack{\text { TFP + vétetlen } \\ \text { tennyezók }}}{y=} A_{2} k^{\alpha_{1}} i^{\alpha_{2}-\alpha_{1}}$

Ez már sokkal korszerúbb vállalati termelési függvény, amely kifejezi, hogy a létszámot nemcsak tárgyi, hanem jelentős immateriális tókével is fel kell szerelni. Mindeddig az immateriális tóke jelenlétére és nagyságrendjére megbízhatóan csak a jövóbeli várható szabad cashflow-k diszkontálásával levezetett vállalati érték és a könyv szerinti érték különbségéból lehetett következtetni (lásd Reszegi, 1999, Juhász, 2004 és Bod 2008). Schultz módszerével azonban az immateriál tóke jelenléte a tényadatok alapján is kimutatható, sớ a nagyságrendje is megbecsülhetổ. Bizonyos tôkehatekonysági feltételezések mellett - például ha feltételezzük, hogy a tárgyi tôke és az immateriális tốke fajlagos hozamai hosszú távon közelítenek egymáshoz - azt mondhatjuk, hogy a két tốke nagyságrendje az $\left(\alpha_{2}-\alpha_{1}\right)$ : $\alpha$ arányhoz közelít.

A harmadik termelési tényezố azonosítása gondolatmenetiink szempontjából azért fontos, met ez egy olyan tóklefajta, amelyet a vállatat sohasen bitokolh olyan tôkefajta, a metyet a válat sohasen bitokolhat teljesen. Az anyagi toke eseteben bizonyos extrém szituációkban ezmeg elképzelhetó, de az inmateriális tóle esetében ez kizárt. Ennek oka az, hogy az immateriális zójától. Azt a hordozója még akkor sem tudja vállalatának teljes mértékben átadni, ha akarja. A tulajdonjog fajtákat az 5. ábra.

Eszerint a vállalat az általa felhasználandó tốkefajtákból csak az anyagi eszközöket $(K)$, valamint a külső $\left(I_{I}{ }^{K}\right)$ és belső $\left(I_{I}{ }^{B}\right)$ immateriális eszközöket tudja magáévá tenni, no meg a különböző tókefajták együtntangible tóke tes tényezôhatékonyságából eredó hasznot (A). A munkavállalók személyes tudását $\left(I_{2}^{T}\right)$, jártasságát $\left(I_{2}^{J}\right)$, motiváltságát $\left(I_{2}^{M}\right)$ csak ideiglenesen tudja megszerezni. Tartósan ezek az eszközök sohasem lesznek az övé. Ezzel kapcsolatban Pollányi Mihály majd Nonaka munkásśa perdöntô, kik értelmezték az emberi tudás tacit dimenzióját, és ezzel jelezték, hogy itt az ens

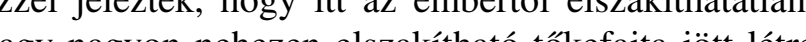
(lás nagyon nehezen elszakín ható tókefajta jott létre (lasd Pollányi, 1994 és Nonaka, 1995 munkát). A vállalatí tókék tulajdonlása ebben az êrtelemben elválik a A vớ ságától a 6 . ábrán látható modell szerint. ${ }^{14}$ A vevő nem tulajdonolható. Fogságba ejthetố, túszszá tehetố (lásd a telekom szektor törekvéseit), de ezek a célok csak korlátozottan érhetốk el. Hưségszerződéssel behúzhatók a vállalat szervezeti tớkéjébe (lásd a $K-I_{{ }^{B}}{ }_{-}$ ${ }^{K}$ metszetet), és ezzel növelhető a birtokolhatósága, de teljessé sohasem tehetô. Hasonlóan fogságba ejthetố a kompetencia is, ha helyzetfüggóvé teszik $\left(T-I^{B}-I\right.$ metszet), és mint ilyet beintegrálják a vállalat szervezeti tókéjébe (mint pl a metróvezetói kompetenciét), de totálisan az soha sem lesz a vállabté (6. abra).

Ezzel a vállalati termelési függvényt újraértelmeztük, és ennek alapján alapkérdésünkkel kapcsolatban a következő választ kaptuk: mivel immateriális tốke nélkül nincs hatékony vállalat, és mivel az immateriális tóke sohasem lehet csak a vállalaté, a vállalat nem függetlenedhet a környezetétól, ahonnan az immateriális tő́ke jelentớs részben származik. A vállalati hatékonyság mindig függvénye lesz a környezet hatékonyságának.

5. ábra

A különböző tốkefajták tulajdonjogáról

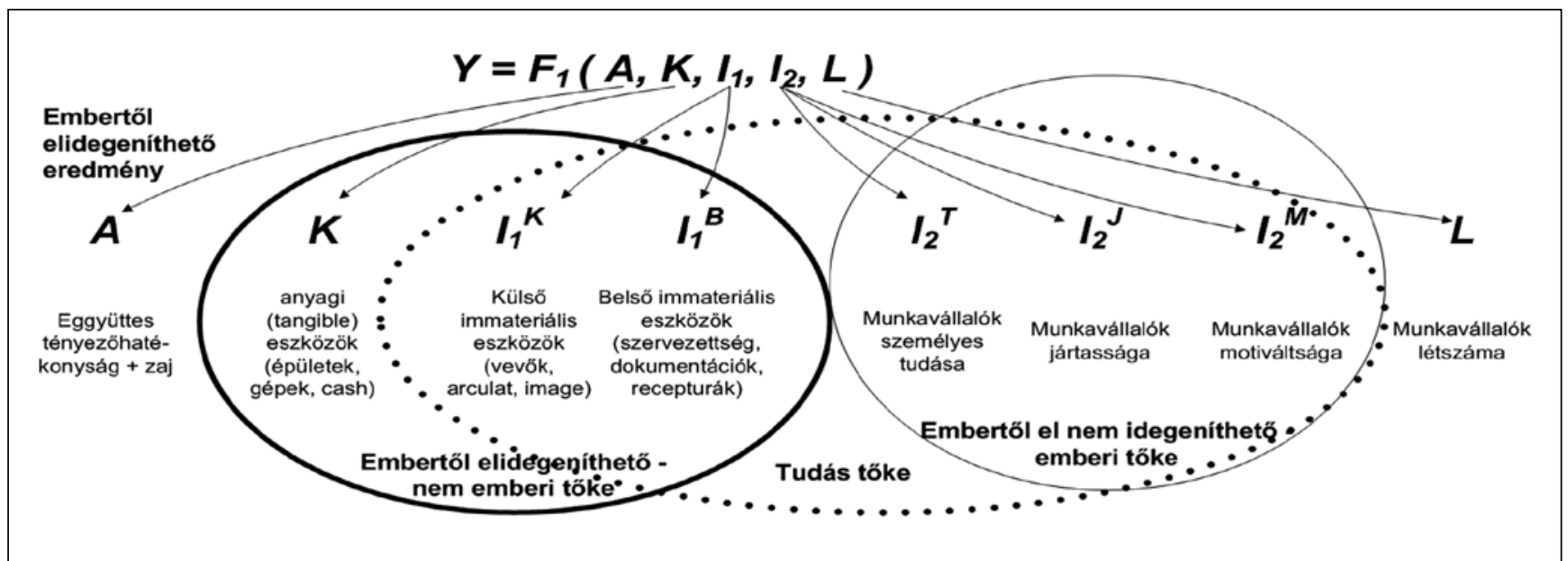

VEZETÉSTUDOMÁNY

XLI. ÉVF. 2010. 7-8. SZÁM / ISSN 0133-0179 


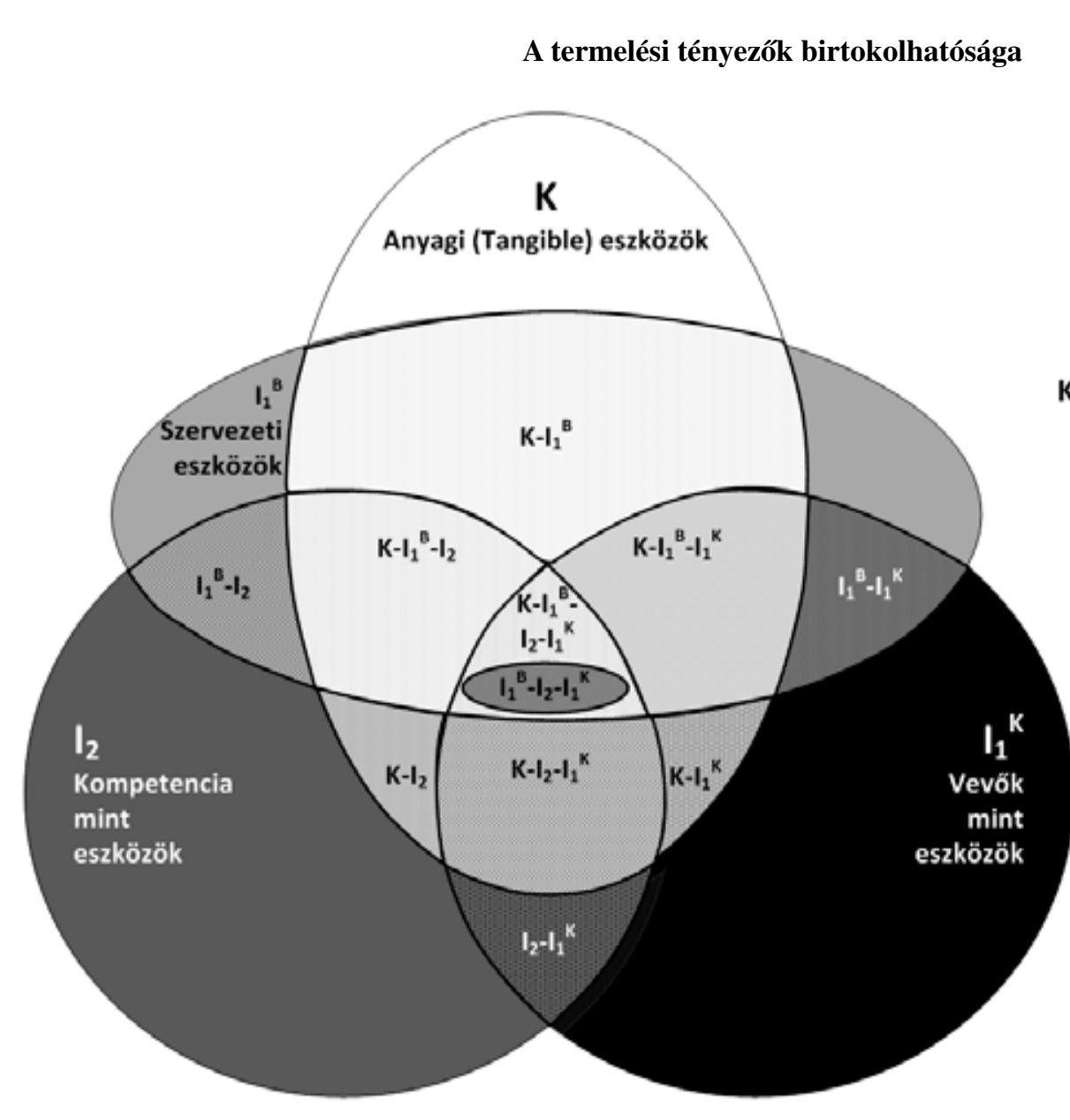

6. ábra

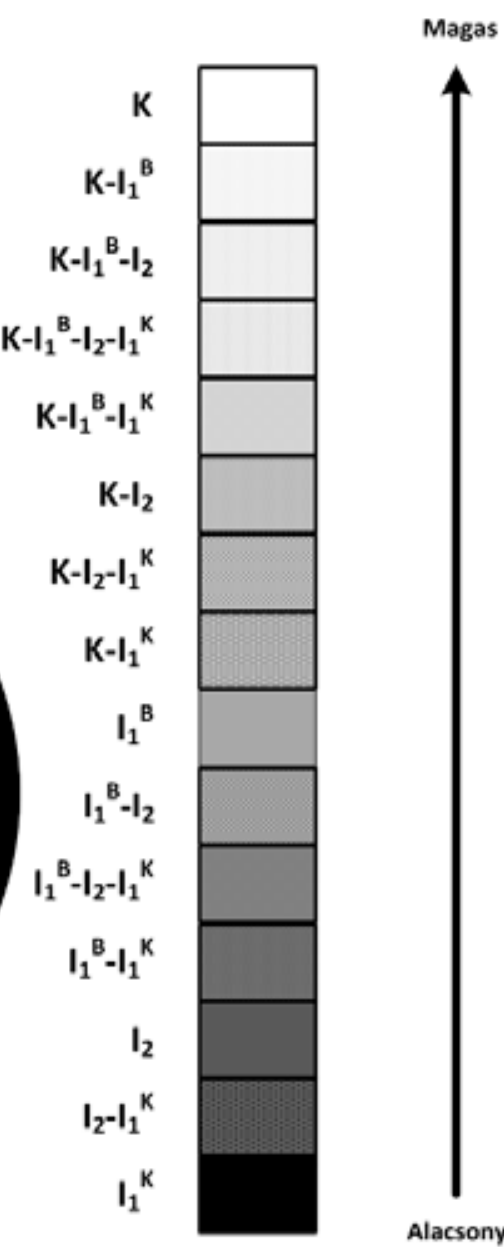

Az n tényezós vállalati termelési függvény

Az 5. ábra már elốrevetítette annak a lehetôségét, hogy a kibocsátást ne csak három, hanem jóval több tényezó függvényeként ragadjuk meg. Az 5. ábra bármely tókeelemének bármilyen diszjunkt felbontása egy értelmezhetố termelési függvvényt eredményez. Ennek alapjân felírhatjuk ezt az általános modellt (7. ábra).

lüli hányadával számítottuk, majd a tókeelemeket k-ra normáltuk. Az egyenlet szerkezete a több tényező ellenémegegyezik a 4. ábrán látható egyenlet szerkezetével. Mivel mi a vállalat határait keressük, rendezzük át a 7. ábra egyenletét a 8. ábrán látható módon!

Itt $k_{l}$ azon anyagi tókék egy fớre jutó mennyiségét jelenti, melyeket a vállalat 100 százalékban tulajdono és birtokol. Ide tartoznak a vállalat alapvetô anyagi ter-$$
\text { melési eszközei, melyeket nem lízin- }
$$

A legrészletesebb felbontású vállalati termelési függvén

$i_{l}$ azon immateriális eszközök egy

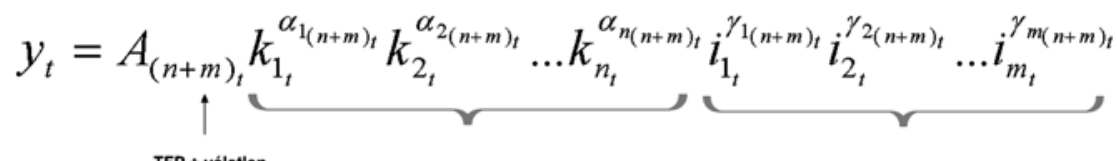
a vállalat igyekszik száz százalékban tulajdonolni és birtokolni. E törekvésében korlátokba ütközik. A vállalat ügyfélkapcsolati rendszere és a szervezettsége ugyan száz százalékban

Itt mind a $K$ tárgyi tókét, mind az I immateriális tố- nem szakítható el az emberektól, de azért magas szinkét diszjunkt elemekre bontottuk, és a kitevőket az adott ten kisajátítható és birtokolható. A kisajátíthatóságnak tókelemre fordított beruházások bruttó fedezeten be- az teremti meg a hátterét, hogy ezek a tốkeelemek nem

VEZETÉSTUDOMÁNY
8. ábra a vállalati vagyon védelmére vagy a dolgozók motiválására. Alacsonyabb oktatási színvonal öveli a vállalat képzési költségeit.

Felemás a középsó, úgynevezett szelektíven használt eszközcsoport szerepe. Ebben egyszerre van jelen a vállalati hatékonyságot növeló társadalmi kooperáció, illetve az azt csökkentő társadalomellenes, és ezáltal mások hatékonyságát rontó deviancia.

A saját eszközök használatának mindenképpen magasabb az ára. Ezen eszközöknek a kapen it́ćt a vállalat a saját piaci lehetőségeihez pacitasát a vallat a sajá piaci lehelósegeihez

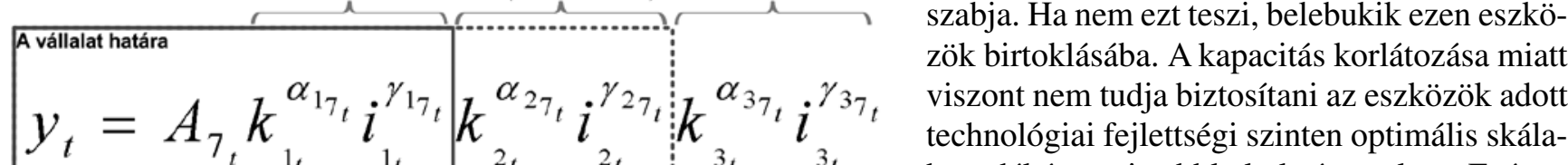

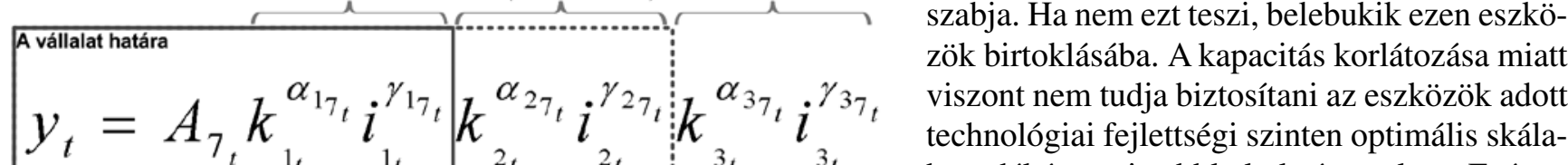
technológiai fejlettségi szinten optimális skála-
hozadékát, ami többletköltséget okoz. Ezért a hozadékát, ami többletköltséget okoz. Ezért a
vállalatnak alapvető érdeke az outsourcing, a mások eszközeire való támaszkodás. Az outsourcing viszont nagyobb kockázatot jelent, amit a vállalat ugyancsak csökkenteni kíván. Ezért az outsourcingnak számos win-win alapú kockázatcsökkentố változata alakul ki. Ilyen az ellátási láncokba való szerveződés vagy a partnership. Ez utóbbi annyira fontos, hogy sokan ezt külön termelési tényezônek tekintik ${ }^{15}$ A partnership például számos esetében insourcingot is jelent a part-

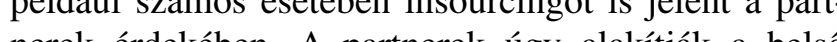
nerek suilo eszköza A parn és kulsô eszközállonányukat - ann a partnerek számára mind belsố eszkôzállományt jelent -, hogy az a partnershipbe szervezóố vállalatok számára minél inkább megközelitse a technikailag optimális kapacitáskihasználást és múködést. Ez a folyamat össztársadalmi szinten pozitív, mert csökkenti a szétaprózottság miatti kapacitáskihasználatlanságokat és ezzel az össztársadalmi hatékonyságot növeli. Baj akkor lesz, ha a partnershipbe szerveződés a társadalom partnershipen kívüli szereplôi ellen irányul.

A korrupció, a törvénytelen összefonódások és a nem kívánatos monopolizálási törekvések is partnershipet jelentenek. Ezek a partnershipek lehetnek szervezettek je mint péld́nt a maffiaszerú egyiütmúködések, vagy néhíny szerón ka né

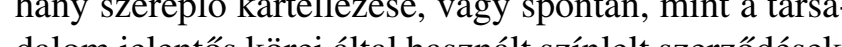
dalom jelentós vagy adócsalás, melyek a központi hatalom gyengesége miatt nyernek teret. Ez a partnership azért veszélyes, mert beavatkozik a társadalom által megtermelt új érték elosztásába, és lehetetlenné teszi a befektetésarányos hozamok keletkezését.

Itt kell kitérni a tớke és az eszköz fogalom közötti $\begin{array}{lll}\text { csak nagyon jelentős, a vállalati hatékonyságot jelen- } & \text { különbségre. A tanulmányban hol a tóke, hol az eszköz } \\ \text { tôsen rontó pótlólagos ráfordításokkal lehetséges. Ha } & \text { szót használtam, noha ezt a két fogalmat nem tekintem } \\ \text { romlik a közbiztonság és a morál, többet kell költeni } & \text { szinonimának. A tanulmány alapján már sejthetố, hogy }\end{array}$ $\begin{array}{lll}\text { csak nagyon jelentős, a vállalati hatékonyságot jelen- } & \text { különbségre. A tanulmányban hol a tóke, hol az eszköz } \\ \text { tôsen rontó pótlólagos ráfordításokkal lehetséges. Ha } & \text { szót használtam, noha ezt a két fogalmat nem tekintem } \\ \text { romlik a közbiztonság és a morál, többet kell költeni } & \text { szinonimának. A tanulmány alapján már sejthetố, hogy }\end{array}$ $\begin{array}{lll}\text { csak nagyon jelentős, a vállalati hatékonyságot jelen- } & \text { különbségre. A tanulmányban hol a tóke, hol az eszköz } \\ \text { tôsen rontó pótlólagos ráfordításokkal lehetséges. Ha } & \text { szót használtam, noha ezt a két fogalmat nem tekintem } \\ \text { romlik a közbiztonság és a morál, többet kell költeni } & \text { szinonimának. A tanulmány alapján már sejthetố, hogy }\end{array}$ romlik a közbiztonság és a morál, többet kell költeni 
legfeljebb csak kiindulópontként tudom elfogadni a korábban idézett Varian-féle tókefogalmat, azonban ennek nemcsak az az oka, hogy a tóke Variannál és mé sokan másoknál csak fizikai, anyagi fogalom, hanem az, hogy a tốke mindig valamilyen tulajdonlást is jelent. Ugyanez a fogalom Marxnál így hangzik: a tốke „a társadalom egy meghatározott része által monopolizált termeló eszközök" ${ }^{16}$ Ha tehát a tóke anyagi tartalmát ki is egészítjük a nem anyagi tartalommal, akkor is meg kell válaszolni azt a kérdést, hogy kié a mögötte objektiválódó - nem csak anyagiasuló - termelóeszköz. Ez jelenik meg egyébként a számviteli szabványok szeEz jelenik neg egy bsén a szan rinti mer megen is, artalm rögzitik az eszkozoldalon, hanem a tulajdonjogat is a forrásoldalon. Magával a tulajuchasssal a tangunán ban több helyen is érdemben foglalkoztam.

Ha a tóke valakié, akkor az számít annak a hozam ra, ugyanis a tóke mögötti eszköz a létrehozója számára fogyasztási áldozat. Ha ezt a hozamot nem kapja meg. akkor az eszköz létrehozása és a fogyasztás korlátozâsa kényszerré válik a számára, és ez csak egy nagyo alacsony hatékonyságú eszközt eredményez. A ma magyar valóság számára keserú tanulság, hogy hova vezet az, ha tele van az ország kényszervállalkozóval, kik csak akkor kaphatnak valamennyire elfogadható jövedelmet, ha a szelektív eszközök mögötti kiskapukat intenzíven használják.

A Cobb-Douglas függvény azért volt nagyon hasznos a gondolkodás során, mert a használt értelmezésben nem abszolút hozamkövetelményekkel dolgozik, ami általában nagyon nehéz megállapítani, hanem arányokkal. Ez a függvény döntően az a kitevớre érzékeny A függvényben a kibocsátást meghatározó tôkeelemeket definiáltuk, amelyek kitevője attól függ, hogy ezen új értékbốl mennyit fordítanak a létrehozásukra. Tehă a tơke kevésbé az abszolút hozamokra érzékeny, inkább az új értékbôl való részesedésre. Ha az abszolút hozan csökken, mint például a most tetốfokához közeledố válságban, akkor még inkább felerốsödik a hozambó való részesedés szerepe.

A pozitív tartalmú partnership azért hasznos, mert mú, a verseny ́́s a társadalmi normák ellen iŕnyubo partnersip viszontánért vesź́lyes, mák ellon irányuló patékonyságától fügrett veszellyes, mert a befektetések a a megtermelt új érték elosztását, és azt függetleníti további befektetésektól. Ha ezen eszközök használa a társadalomban elterjed, az kiszámíthatatlanná teszi, hogy valamilyen befektetésból milyen hozam várható. Egy váratlan kartell kisvállalkozók ezreit teheti tönkre. Egy elharapódzott negatív társadalmi gyakorlat - pl. adóelkerülés - felszámolása ugyancsak kiszámíthatatlan hatású. Ez mindenképpen kényszerpályára löki azokat a vállalatokat, amelyek nem tudnak, vagy tisztelet nekik - tudnának, de nem akarnak a negatív partnership útjára lépni. Ennek természetes következménye a befektetések torzulása, illetve visszafogása. Mivel ezektól a vállalat nem tudja hermetikusan lezárni a határait, mindenképpen romlik a hatékonysága. Ha a jövedelmek torz elosztása miatt lényeges $k_{3}$-as és $i_{3}$-as befektetések elmaradnak, akkor a vállalatnak a saját k és $i_{1}$ befektetéseit kell növelni, és ezt az alaezt az alacsony skálahozadék miatt csak alacsonyabb hatékonyKágal tudja megvalósítani.

Külön probléma, hogysha a szelektív eszközök e negatív tartalmú használata kiterjed, akkor pont ellenkező lesz a hatás: a vállalati hatékonyság jelentôsen romlik, ugyanis a védekezés ellenük pótlólagos ráfordításokat okoz. Vagy azért, mert be kell szállni a játékba, vagy azért, mert a játék következtében fellépố belső hatékonyságromlást további ráfordításokkal kell ellentételezni.

Hogyan alakul egy Richter típusú vállalat helyzete az elmondottak függvényében? Mondhatja-e azt Bogsch Erik, hogy „nekem már jô”, „én nagyra nőttem”, ,rám már ezek a folyamatok nem hatnak”? Szerintem ő már megérezte, hogy a bachelor képzésnek

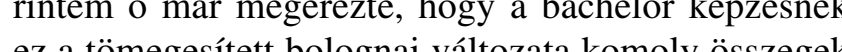
ez a tón thro továni tén ráforditassra lesz szüksége, ha nem tud hatékonyan támaszkodni a magyar egy,temek kutoló kapacitasaira. Ha valaki, ố érzi, hogy még egy olyan nagyvállalat, mint a Richter, sem képes arra, hogy bezárkózzon az elektronikus beléptető rendszere mögé. Ami kint történik, az az ô hatékonyságára is kihat.

A 8. ábrán értelmezett vállalati termelési függvény új megvilágításba helyezi a Solow reziduálist. Ha a TFP-t kizárólag csak a vállalaton belüli tôkék és lét-

\section{Következtetések}

Egy vállalat egy adott hatékonyságú társadalomba mindig megkísérli elkülöníteni a termelési tényezók egy részét, és azt a maga kizárólagos monopóliumává tenn (saját gép, saját épület, saját vevőkör, saját kapcsolatrendszer, titkosított tudás stb.). Van a termelési tényezóknek egy másik csoportja, amelyet a vállalatok meg sem kísérelnek magukévá tenni, mivel ezt csak irracionális költségáldozatokkal tehetnék ( $\mathrm{Pl}$ saját vasút- vagy autópálya-hálózat élethosszig garantált foglalkoztat́s

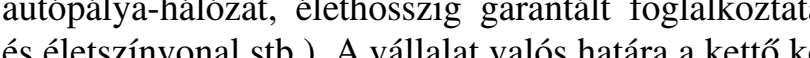
es életszzött húzódik. Hogy pontosan hol, az attól függ, hogy
vállalat miként él a partnership lehetôségeivel.

A partnership egy kétélú termelési eszköz. Ha a A partnership egy kétélú termelési eszköz. Ha a
társadalom jól használja, akkor a munkamegosztás és a vállalatok közötti kooperáció fejlódését gyorsítja, többi termelési tényező hatékonyságát növeli és pótlólagos hozamot biztosít. Ha a partnership a verseny és a társadalmi együttélés normái ellen irányul, akkor aláássa a termelési tényezók fejlesztésének harmonikus folyamatát, és elóbb-utóbb a társadalmi és azon keresztül a vállalati hatékonyság romlásához vezet.

Egy biztos! Akárhogy is definiáljuk a vállalat határait, a vállalat termelési függvénye nem ér véget a vállalat határainál, és így a vállalati kibocsátás a társadalom más területein - más vállalatokban, más közintézményekben stb. - lekötött tốkéktől alapjában függ, és azok hatékonyságától nem lehet független. A bezárkózás átmenetileg növelheti a hatékonyságot mindaddig amíg a vállalat számára leginkább hatékonyságromb ló tevékenységektőll függetlenedik, de ennek termelesi tényezőit magának kell kiépíteni a maga definiálta határokon belül, és ez a saját hatékonyságát mind a ráfordításigény, mind a romló skálahozadék okán lerontja és ez így zsákutca. Emiatt végül hatékony vállalat csak hatékony társadalomban építhetố fel.

A vállalati határokon átnyúló termelési függvénynek van még egy fontos következménye. A vállalati hatékonyság akkor bontakozik ki, ha a termelési tényezók fejlődése a társadalom egészében harmonikus, abban nem keletkeznek szúk keresztmetszetek. A szúk keresztmetszetek - ahogy a leglassúbb teve lelassítja a karavánt -, úgy lelassítják a vállalati hatékonyság növekedését. Nem lehetséges optimális vállati fejő́dés va a vállalaton lín

Ezért a bezárkózás nem vezet stratégiai megoldáshoz. A magyar történelemben erre számos példa volt. Amikor a társadalom hatékonysága lecsökkent - ennek legszélsőségesebb esetére a törökkel folytatott küzdelmek idején került sor -, akkor jelentős tömegek kényszerültek egyéni stratégiai megoldásokra, de ebbő́l csak problémák fakadtak. Megnőtt az önbíráskodás, az önvédelem szerepe, és ebbôl olyan súlyos problémák keletkeztek, mint a rablás, az útonállás, a hajdúk letelepítése, vagy a kurucok újbóli szocializálása. A haladást megvalósító központi hatalomnak ezekkel a tendenciákkal meg kellett küzdenie, mert ezek nem vezettek hatékony alaptevékenységhez a társalom alapegységéten - csáádokban, egyéb mikroközösségekben - És nem erósít té́k az orsźgot, a birodalmat, sốt gyengítették. Manapság ennyire a birada rosszul, de a feladat ugyanaz: helyre kell állítani azt a közbizalmat, mely lehetôvé teszi, hogy a vállalatok bátran támaszkodhassanak a határaikon kívüli termelési tényező́kre.

\section{FÜGGELÉK} a befektetések hatékonyságát növeli, és ezzel aŕnyos hozannövekedést eredénez. A negáiv tantoszám segítségével kívánjuk meghatározni, akkor mindig magabb étéket kapunk a valós vállakkor min-

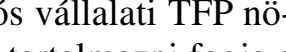
vekedésenél, mert ez a TFP-javulás tartalmazni fogja a vállalaton kívül felhasznált idegen, vagy társadalmi tốké hozzajar ulását a vâllalati hatékonysăg noovekedéséhez. Gondoljunk az autópálya-hasonlatunk tanulságára. A vállalati TFP-t csak akkor lehet pontosan meghatározni, ha minden termelési tényezôt azonosítottunk, mely a vállalati kibocsátást termelik. A hagyományos vállalati termelési függvényszámítások többnyire csak a vállalaton belüli termelési tényezókboól indulnak ki. Ezért az ilyen típusú vállalati TFP-számítások nem is lehetnek helyesek.

A Cobb-Douglas függvény átalakítása

$$
\begin{gathered}
Y_{t}=A_{t} K_{t}^{\alpha_{t}} L_{t}^{\beta_{t}} \\
Y_{t} / L_{t}=A_{t} K_{t}^{\alpha_{t}} L_{t}^{\beta_{t}} / L_{t} \\
Y_{t} / L_{t}=A_{t} K_{t}^{\alpha_{t}} L_{t}^{\beta_{t}} / L_{t}^{\alpha_{t}} L_{t}^{\beta_{t}} \\
Y_{t} / L_{t}=A_{t}\left(K_{t}^{\alpha_{t}} / L_{t}^{\alpha_{t}}\right) \\
y_{t}=A_{t} k_{t}^{\alpha_{t}}
\end{gathered}
$$

VEZETÉSTUDOMÁNY
A háromtényezốs termelési függvény átalakítása

\section{Idôindex végiggondolásával}

$Y_{t}=A_{2} K_{t}^{\alpha_{1 t}} L_{t}^{\beta_{2 t}} I_{t}^{\gamma_{2 t}}$ ahol $\quad \gamma_{2}=\alpha_{2}-\alpha_{1}$

$Y_{t} / L_{t}=A_{2} K_{t}^{\alpha_{1 t}} L_{t}^{\beta_{2 t}} I_{t}^{\gamma_{2}} / L_{t}$

$Y_{1} / L_{t}=A_{2} K^{\alpha_{1 t}} L_{t}^{\beta_{2 t}} I_{1}^{\gamma_{2 t}} / L_{t}^{\alpha_{1 t}} L_{t}^{\beta^{{ }_{2 t}}} L_{t}^{\gamma_{2 t}}$

$Y_{t} / L_{t}=A_{2 t}\left(K_{t}^{\alpha_{1 t}} / L_{t}^{\alpha{ }_{1 t}}\right)\left(I_{t}^{\gamma{ }_{2 t} / L_{t}^{\gamma}{ }_{2_{t}}}\right)$ $y_{t}=A_{2}, k_{t}^{\alpha_{1}} i_{t}^{\gamma_{2}}$

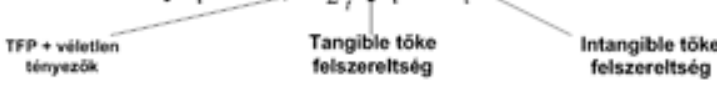


A termelési fügovény számítások dokumentálása

\begin{tabular}{|c|c|c|c|c|c|c|c|c|c|}
\hline & 1 & 2 & 3 & 4 & 5 & 6 & 7 & 8 & 9 \\
\hline & $\begin{array}{l}\text { Árbevé- } \\
\text { tel } \\
\text { (Mrd Ft) }\end{array}$ & $\begin{array}{c}\text { Bruttó } \\
\text { fedezet } \\
\text { (Mrd Ft) }\end{array}$ & $\begin{array}{c}\text { Beruhá- } \\
\text { zások } \\
\text { (Mrd Ft) }\end{array}$ & $\begin{array}{c}\text { Befekte- } \\
\text { tett } \\
\text { eszközök } \\
\text { (Mrd Ft) }\end{array}$ & $\begin{array}{c}\text { Eszköz } \\
\text { (Mrd Ft) }\end{array}$ & $\begin{array}{l}\text { Létszám } \\
\text { (fö) }\end{array}$ & $\begin{array}{l}\text { Személyi } \\
\text { jellegú } \\
\text { ráfordí- } \\
\text { tások }\end{array}$ & ALFA 1 & ALFA 2 \\
\hline & Input & Input & Input & Input & Input & & & $=2 / 3$ & $=1-6 / 3$ \\
\hline 1992 & 13089 & 7601 & 953 & 13850 & & 5274 & & 0,125 & \\
\hline 1993 & 17957 & 11252 & 1615 & 13558 & & 4800 & & 0,144 & \\
\hline 1994 & 21196 & 13321 & 3140 & 15083 & & 4626 & & 0,236 & \\
\hline 1995 & 27394 & 16994 & 4898 & 17928 & & 4533 & & 0,288 & \\
\hline 1996 & 36764 & 22514 & 6659 & 23116 & & 4436 & & 0,296 & \\
\hline 1997 & 52016 & 27956 & 9469 & 30773 & & 4450 & & 0,339 & \\
\hline 1998 & 55063 & 30433 & 14736 & 45981 & & 4575 & & 0,484 & \\
\hline 1999 & 59554 & 32452 & 15608 & 58444 & & 4730 & & 0,481 & \\
\hline 2000 & 74107 & 44509 & 17366 & 70200 & & 4835 & & 0,390 & \\
\hline 2001 & 88731 & 53125 & 14934 & 83173 & & 5007 & & 0,281 & \\
\hline 2002 & 120013 & 60207 & 17419 & 95572 & 175243 & 6950 & & 0,289 & \\
\hline 2003 & 145916 & 78601 & 21948 & 103853 & 199575 & 7328 & & 0,279 & \\
\hline 2004 & 149342 & 78246 & 26812 & 122582 & 234932 & 7260 & 35534 & 0,343 & 0,546 \\
\hline 2005 & 172597 & 97024 & 29871 & 140117 & 277580 & 8078 & 41146 & 0,308 & 0,576 \\
\hline 2006 & 209373 & 119699 & 32351 & 160677 & 325784 & 8526 & 48601 & 0,270 & 0,594 \\
\hline 2007 & 224076 & 119697 & 23197 & 175487 & 347963 & 9528 & 49514 & 0,194 & 0,586 \\
\hline 2008 & 236518 & 128097 & 22010 & 171057 & 384133 & 10527 & 55421 & 0,172 & 0,567 \\
\hline
\end{tabular}

Az abszolút adatok forrása

szám A konszolidált pénzügyi adatok összefoglalója 2003-200s szám A konszolidált pénzügyi adatok összefoglalója 2003-2007 szám A konszolidâlt pènzugVi adatok osszefoglaloja 2002-2006 szám A konszolidâlt penzügyi adatok osszefoglalója 2002-2005 szám A konszolidált pénzügyi adatok összefoglalója 1992-2004

A Richter Rt. kibocsátása, eszközállománya és beruházási hányadai

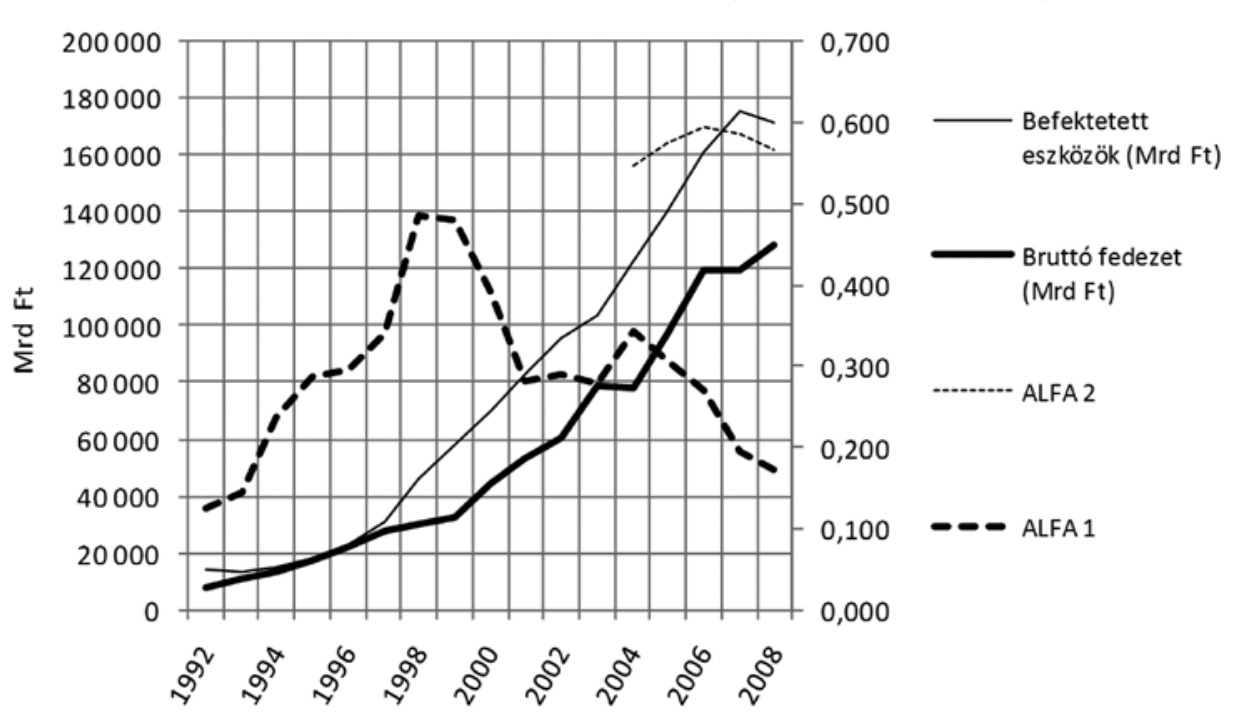

VEZETÉSTUDOMÁNY
A vállalati termelési fügovény valós (Richter) adatok mellett $\alpha_{1}$ beruházási hányaddal

\begin{tabular}{|c|c|c|c|c|c|c|c|c|c|c|c|c|c|}
\hline \multirow[b]{2}{*}{ Ev } & \multicolumn{4}{|c|}{ Richter inputok } & \multicolumn{4}{|c|}{ A temelési függvény $\alpha_{1}$ mellett } & \multirow{2}{*}{\multicolumn{5}{|c|}{$\begin{array}{l}\text { A termelési függvény összetevő́ine } \\
\text { elemzése }\end{array}$}} \\
\hline & $\begin{array}{c}\text { Hozzáadott } \\
\text { érték } \\
\text { (Bruttó } \\
\text { fedezet) } \\
\text { (Mrd Ft) }\end{array}$ & $\begin{array}{c}\text { Befekte- } \\
\text { tett } \\
\text { eszközök } \\
\text { (Mrd Ft) }\end{array}$ & \begin{tabular}{|c} 
Foglalkoz- \\
tatottak \\
létszáma \\
(Fö)
\end{tabular} & \begin{tabular}{|c} 
Anyagi \\
beruházási \\
hányad \\
$(\%)$
\end{tabular} & $\begin{array}{c}\text { Munka- } \\
\text { terme- } \\
\text { lékenység } \\
\text { (Mrd Ft/fö) }\end{array}$ & $\begin{array}{c}\text { Anyagi } \\
\text { tökefel- } \\
\text { szereltség } \\
\text { (Mrd Ft/fö) }\end{array}$ & $\begin{array}{c}\text { Anyagi } \\
\text { tókével } \\
\text { létrehozott } \\
\text { új érték } \\
\text { (Mrd Ft/fó) }\end{array}$ & $\begin{array}{c}\text { A TFP által } \\
\text { létrehozott } \\
\text { új érték +a } \\
\text { zaj } \\
(\text { Mrd Ft/fól) }\end{array}$ & & & & & \\
\hline $\mathrm{t}$ & $Y_{t}$ & $k_{t}$ & $L_{t}$ & $\alpha_{4}$ & $y_{t}=Y_{t} / L_{t}$ & $k_{t}=k_{t} / L_{t}$ & $\mathrm{k}_{\mathrm{t}}^{\text {at }}$ & $A_{t}=y_{t} / k_{t}{ }^{\alpha t}$ & $\ln y_{t}$ & $\ln \mathrm{k}_{\mathrm{t}}^{\text {at }}$ & $\ln A_{t}$ & $\ln k_{t}^{\alpha t}$ & \\
\hline 1990 & 7601 & 13850 & 5274 & 0,1 & 1,44 & 2,63 & 1,13 & 1,28 & 0,37 & 0,12 & 0,24 & $33 \%$ & $67 \%$ \\
\hline 1991 & 11252 & 13558 & 4800 & $0,1<$ & 2,34 & 2,82 & 1,16 & 2,02 & 0,85 & 0,15 & 0,70 & $17 \%$ & $83 \%$ \\
\hline 1992 & 13321 & 15083 & 4626 & 0,26 & 2,88 & 3,26 & 1,32 & 2,18 & 1,06 & 0,28 & 0,78 & $26 \%$ & $74 \%$ \\
\hline 1993 & 16994 & 17928 & 4533 & 0,25 & 3,75 & 3,95 & 1,49 & 2,52 & 1,32 & 0,40 & 0,93 & $30 \%$ & $70 \%$ \\
\hline 1994 & 22514 & 23116 & 4436 & 0,30 & 5,08 & 5,21 & 1,63 & 3,11 & 1,62 & 0,49 & 1,14 & $30 \%$ & $70 \%$ \\
\hline 1995 & 27956 & 30773 & 4450 & 0,3 & 6,28 & 6,92 & 1,93 & 3,26 & 1,84 & 0,65 & 1,18 & $36 \%$ & $64 \%$ \\
\hline 1996 & 30433 & 45981 & & 0,48 & 6,65 & 10,05 & 3,06 & 2,18 & 1,89 & 1,12 & 0,78 & $59 \%$ & $41 \%$ \\
\hline 1997 & 32452 & 58444 & 47 & 0,4 & 6,86 & 12,36 & 3,3 & 2,05 & 1,93 & 1,21 & 0,72 & $63 \%$ & $37 \%$ \\
\hline 1998 & 44509 & 70200 & 4835 & 0,35 & 9,21 & 14,52 & 2,84 & 3,24 & 2,22 & 1,04 & 1,18 & $47 \%$ & $53 \%$ \\
\hline 1999 & 53125 & 83173 & 5007 & $0,2 \varepsilon$ & 10,61 & 16,61 & 2,20 & 4,82 & 2,36 & 0,79 & \begin{tabular}{l|l}
9 & 1,57 \\
\end{tabular} & $33 \%$ & $67 \%$ \\
\hline & 60207 & & & 0,26 & 8,66 & 13,75 & 2,13 & 4,06 & 2,16 & 0,76 & 1,40 & $35 \%$ & $65 \%$ \\
\hline 2001 & 78601 & & & 0,28 & 10,73 & 14,17 & 2,10 & 5,12 & 2,37 & 0,74 & 1,63 & $31 \%$ & $69 \%$ \\
\hline 2002 & 78246 & 122582 & 7260 & 0,3 & 10,78 & 16,88 & 2,63 & 4,09 & 2,38 & 0,97 & 1,41 & $41 \%$ & $59 \%$ \\
\hline 2003 & 97024 & 140117 & 8078 & 0,3 & 12,01 & 17,35 & 2,41 & 4,99 & 2,49 & 0,88 & 1,61 & $35 \%$ & $65 \%$ \\
\hline 2004 & 119699 & 160677 & 8526 & 0,22 & 14,04 & 18,85 & 2,21 & 6,35 & 2,64 & 0,79 & 1,85 & $30 \%$ & $70 \%$ \\
\hline 2005 & 119697 & 175487 & 9528 & 0,15 & 12,56 & 18,42 & 1,76 & 7,1 & 2,53 & 0,56 & 1,97 & $22 \%$ & $78 \%$ \\
\hline 2006 & 128097 & 171057 & 10527 & 0,17 & 12,17 & 16,25 & 1,61 & 7,54 & 2,50 & 0,48 & $3,2,02$ & $19 \%$ & $81 \%$ \\
\hline
\end{tabular}

$a_{1}$ felhalmozási hányadhoz tartozó tốke becslése

F3. táblázat

\begin{tabular}{|c|c|c|c|c|c|c|c|c|c|c|}
\hline \multirow[b]{3}{*}{$\begin{array}{c}\text { Becsült } \\
\text { beru- } \\
\text { házási } \\
\text { hányyad }\end{array}$} & \multirow[b]{3}{*}{$\begin{array}{c}\text { Beruhá- } \\
\text { zások }\end{array}$} & & & & & \multicolumn{2}{|c|}{$\begin{array}{l}\text { Leirások átlagos szinttje } \\
\text { Amortizációs kulcs: }\end{array}$} & \multicolumn{3}{|c|}{$50,0 \%$} \\
\hline & & \multicolumn{4}{|c|}{ Befektetett eszközök bruttó értéke } & \multicolumn{4}{|c|}{$\begin{array}{l}\text { Értékcsöökkenés } \\
\end{array}$} & \multirow{2}{*}{$\begin{array}{l}\text { Beféktetett } \\
\text { eszközöök } \\
\text { nettó } \\
\text { étékének } \\
\text { záró- } \\
\text { állománnya }\end{array}$} \\
\hline & & $\begin{array}{l}\text { Nyitó állo- } \\
\text { mány }\end{array}$ & $\begin{array}{l}\text { Üzembe- } \\
\text { helyezés }\end{array}$ & $\begin{array}{l}\text { Selej- } \\
\text { tezés }\end{array}$ & $\begin{array}{c}\text { Záróáallo- } \\
\text { mány }\end{array}$ & $\begin{array}{c}\text { Kummulált } \\
\text { amortizáció } \\
\text { nyitó- } \\
\text { allománya }\end{array}$ & $\begin{array}{l}\text { Növek- } \\
\text { mény }\end{array}$ & $\begin{array}{c}\text { Selejte- } \\
\text { zés } \\
\text { amortizá- } \\
\text { cójja }\end{array}$ & $\begin{array}{c}\text { Kummulált } \\
\text { amortizáció } \\
\text { záró- } \\
\text { állománya }\end{array}$ & \\
\hline$\alpha_{1, \mathrm{t}}$ & $\alpha_{1, t} Y_{t}$ & $\mathbf{K}_{\mathrm{t}, \text { nyitó }}^{\mathrm{b}}$ & $\alpha_{1, t} Y_{t}$ & $s_{\mathrm{t}}$ & $\mathbf{K}_{\mathrm{t}, \mathrm{z} a ́ r o ́}^{\mathrm{b}}$ & $D_{t, \text { nyitó }}^{k}$ & $D_{t}$ & $D_{t}^{s}$ & $\mathbf{D}_{\mathrm{t}, \text { záró }}^{\mathbf{k}}$ & $\mathrm{K}_{\mathrm{t}}^{\prime}$ \\
\hline 0,347 & 3473 & 34374 & 3473 & 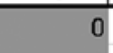 & 37847 & 17187 & 2407 & 0 & 19594 & 182 \\
\hline 0,347 & & 37847 & & 0 & & & 2661 & & 22255 & 19 \\
\hline 0,347 & 4919 & 41980 & 4919 & 0 & 46899 & 22255 & 2963 & & 25218 & 21681 \\
\hline 0,347 & 5853 & 46899 & 5853 & 0 & 52752 & 25218 & 3322 & & 28539 & 24213 \\
\hline 0,3 & & & & & & & & 0 & 322 & 27429 \\
\hline & & & & & & & & & & \\
\hline & & & & & & & & & & \\
\hline 0,347 & 11738 & & 11738 & 0 & & & & & 91 & 426 \\
\hline & & & & & 76 & & & 0 & 31 & 50145 \\
\hline & & & & & 120 & & & & 60890 & \\
\hline 0,347 & 19780 & & & 0 & 139 & & 8672 & 0 & 69562 & 706 \\
\hline & & & & & & & & 0 & 79679 & \\
\hline & & & & & & & & & & \\
\hline & & & & 0 & & & & 0 & & \\
\hline 0,347 & 39665 & & 396 & 0 & & 105393 & 16313 & 0 & 121705 & \\
\hline 0,347 & 47202 & 264523 & 47202 & 3473 & 308251 & 121705 & 19092 & 3473 & 137324 & 170927 \\
\hline & & & & & & & & & & \\
\hline
\end{tabular}


$\boldsymbol{\alpha}_{2}$ felhalmozási hányadhoz tartozó tốke becslése

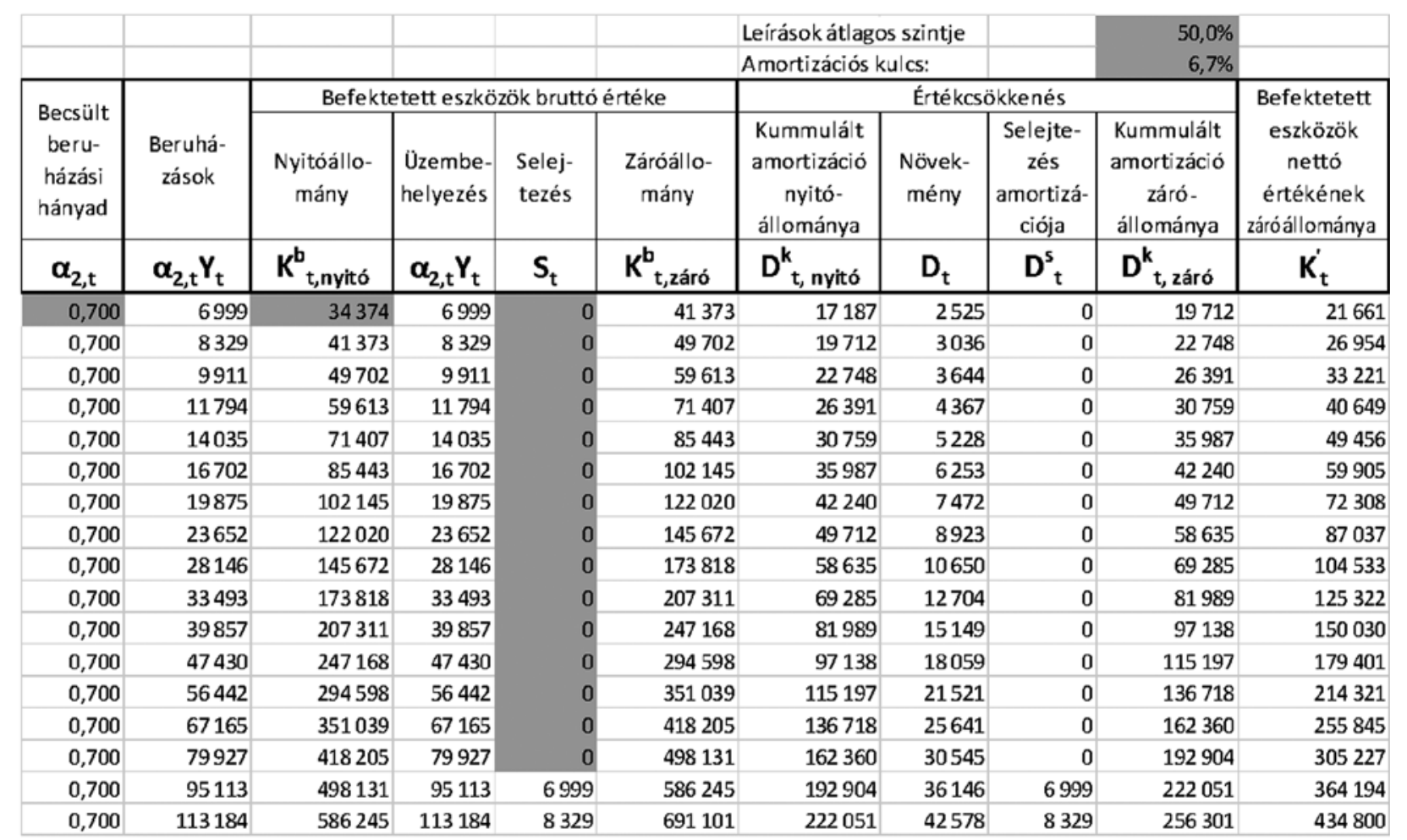

A vállalati trendesített adatokkal $\alpha_{2}$ beruházási hányaddal

F5. táblázat

\begin{tabular}{|c|c|c|c|c|c|c|c|c|c|c|c|c|c|}
\hline \multirow[b]{2}{*}{ Év } & \multicolumn{4}{|c|}{ Trendesített és a megemelt $\alpha_{2}$ beruházási } & \multicolumn{4}{|c|}{ A termelési függvény $\alpha_{2}$ mellett } & \multirow{2}{*}{\multicolumn{5}{|c|}{$\begin{array}{l}\text { A termelési függvény összetevöinek } \\
\text { elemzése }\end{array}$}} \\
\hline & $\begin{array}{l}\text { Hozzáadott } \\
\text { érték } \\
\text { (Bruttó } \\
\text { fedezet) } \\
\text { (Mrd Ft) }\end{array}$ & 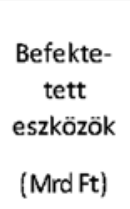 & $\begin{array}{c}\text { Foglalkoz- } \\
\text { tatottak } \\
\text { létszáma } \\
\text { (Fö) }\end{array}$ & \begin{tabular}{|c|}
$\begin{array}{c}\text { Anyagi } \\
\text { beruházási } \\
\text { hányad } \\
(\%)\end{array}$ \\
\end{tabular} & $\begin{array}{c}\text { Munka- } \\
\text { terme- } \\
\text { lékenység } \\
\text { (Mrd Ft/fó) }\end{array}$ & $\begin{array}{c}\text { Anyagi } \\
\text { tökefel- } \\
\text { szereltség } \\
\text { (Mrd Ft/fó) }\end{array}$ & \begin{tabular}{|c} 
Anyagi \\
tókével \\
létrehozott \\
új érték \\
(Mrd Ft/fö)
\end{tabular} & $\begin{array}{c}\text { A TFP által } \\
\text { létrehozott } \\
\text { cujjérték +a } \\
\text { zaj } \\
\text { (Mrd Ft/fö) }\end{array}$ & & & & & \\
\hline $\mathbf{t}$ & $\mathbf{Y}_{\mathrm{t}}$ & $\mathrm{k}_{\mathrm{t}}$ & $L_{t}$ & $\alpha_{t}$ & $y_{t}=Y_{t} / L_{t}$ & $k_{t}=k_{t} / L_{t}$ & $k_{t}{ }^{a t}$ & $A_{t}=y_{t} / k_{t}{ }_{t}^{t t}$ & $\ln y_{t}$ & $\ln k_{t}^{\alpha t}$ & $\ln A_{t}$ & $\left|\begin{array}{ll}\ln k_{t}^{\alpha e t} \\
\ln y_{t}\end{array}\right|$ & \\
\hline 1990 & 9999 & 21661 & 3912 & 0,70 & 2,56 & 5,54 & 3,31 & $0, \pi$ & 0,94 & 1,20 & $-0,26$ & $128 \%$ & $-28 \%$ \\
\hline 1991 & 11898 & 26954 & 4121 & 0,70 & 2,89 & 6,54 & 3,72 & 0,78 & 1,06 & 1,31 & $-0,25$ & $124 \%$ & $-24 \%$ \\
\hline 1992 & 14159 & 33221 & 4342 & 0,70 & 3,26 & 7,65 & 4,16 & 0,78 & 1,18 & 1,42 & $-0,24$ & $121 \%$ & $-21 \%$ \\
\hline 1993 & 16849 & 40649 & 4574 & 0,70 & 3,68 & 8,89 & 4,61 & 0,80 & 1,30 & 1,53 & $-0,23$ & $117 \%$ & $-17 \%$ \\
\hline 1994 & 20051 & 49456 & 4818 & 0,70 & 4,16 & 10,26 & 5,10 & $0,0,82$ & 1,43 & 1,63 & $-0,20$ & $114 \%$ & $-14 \%$ \\
\hline 1995 & 23860 & 59905 & 5076 & 0,70 & 4,70 & 11,80 & 5,63 & 0,84 & 1,55 & 1,73 & $-0,18$ & $112 \%$ & $-12 \%$ \\
\hline 1996 & 28394 & 72308 & 5347 & 0,70 & 5,31 & 13,52 & 6,19 & 0,86 & 1,67 & 1,82 & $-0,15$ & \begin{tabular}{|l|l|}
$109 \%$ \\
\end{tabular} & $-9 \%$ \\
\hline 1997 & 33788 & 87037 & 5633 & 0,70 & 6,00 & 15,45 & 6,80 & 0,88 & 1,79 & 1,92 & $-0,12$ & $107 \%$ & \\
\hline 1998 & 40208 & 104533 & 5934 & 0,70 & 6,78 & 17,62 & 7,45 & 0,91 & 1,91 & 2,01 & $-0,09$ & $105 \%$ & \\
\hline 1999 & 47848 & 125322 & 6251 & 0,70 & 7,65 & 20,05 & 8,16 & 0,94 & 2,04 & 2,10 & $-0,06$ & $103 \%$ & $-3 \%$ \\
\hline 2000 & 56939 & 150030 & 6585 & 0,70 & 8,65 & 22,78 & 8,92 & 0,97 & 2,16 & 2,19 & $-0,03$ & \begin{tabular}{|l|l|}
$101 \%$ \\
\end{tabular} & $-1 \%$ \\
\hline 2001 & 67757 & 179401 & 6937 & 0,70 & $9, \pi 7$ & 25,86 & 9,75 & 1,00 & 2,28 & 2,28 & 0,00 & \begin{tabular}{|l|l|}
$100 \%$ \\
\end{tabular} & $0 \%$ \\
\hline 2002 & 80631 & 214321 & 7308 & 0,70 & 11,03 & 29,33 & 10,64 & 1,04 & 2,40 & 2,36 & 0,04 & $99 \%$ & $1 \%$ \\
\hline 2003 & 95951 & 255845 & 7699 & 0,70 & 12,46 & 33,23 & 11,62 & 1,07 & 2,52 & 2,45 & 0,07 & $97 \%$ & $3 \%$ \\
\hline 2004 & 114181 & 305227 & 8110 & 0,70 & 14,08 & 37,63 & 12,67 & 1,11 & 2,64 & 2,54 & 0,11 & $96 \%$ & $4 \%$ \\
\hline 2005 & 135875 & 364194 & & 0,70 & 15,90 & 42,63 & 13,83 & 1,15 & 2,77 & 2,63 & 0,14 & $95 \%$ & $5 \%$ \\
\hline 2006 & 161692 & 434800 & 9000 & 0,70 & 17,96 & 48,31 & 15,09 & 1,19 & 2,89 & 2,71 & 0,17 & $94 \%$ & \\
\hline
\end{tabular}

VEZETÉSTUDOMÁNY

\section{Lábjegyzet}

Ezzel a kérdéssel részletesen foglalkozik Boda György (2010) Utemvakság címú, jelenleg megjelenés alatt álló tanulmánya. A dolgozat a GDP hosszú távú reálnövekedésének elemzése 1995-2002 közötti gyorsabb növekedési periódus csak egy válság utáni helyreállitáasi periódus volt, és a rendszerváltás után $\mathrm{k}$ alakuló magyar kapitalizmus csak a magyarországi szocializmus múködése során kialakult hosszú távú növekedési ütemet állította helyre. Ez mintegy fele az Egyesültt Államok hosszú távú növe-

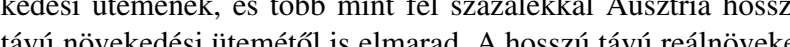
dési ütem felgyorsításával a magyar kapitalizmus egyelốre még adós maradt.

Lásd a Corvinus Egyetemen és a vezetó magyar egyetemeken használt tankönyvek közül P. A. Samuelson Közgazdaságtan címú könyvét, Hal. R. Varian Mikroökonómia középfokon cím tankönyvét és N. Gregory Mankiw Makroökonómia címú tan-

könyvét.
Lásd Mankiw (2003) 79. és 107-109. oldalakat.

Varian: Mikroökonómia középfokon, 333. old

Az átalakitas matematikai levezetését lásd a függelékben ,A "Az

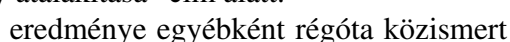
jelenség. Erról a Vállalatgazdaságtan Intézetben folyó kutatósok Példánkban $\mathrm{A}_{\mathrm{t}-1} \mathrm{kt}^{\mathrm{at}-1}-\mathrm{A}_{\mathrm{t}-1} \mathrm{k}_{\mathrm{t}-1}{ }^{\mathrm{at}-1}$, vagy $\mathrm{A}_{\mathrm{t}} \mathrm{k}^{\mathrm{at}}-\mathrm{A} \mathrm{k}-1^{\mathrm{a}}$.

SCHULTZ, (1983): „Meggyóző́désem, hogy ha a gazdasági novekedésról elmelkedunk, akkor a beruházások oldalárol kell megközelítenünk a dolgot. Ebben a felfogásban a tốkeállomán a beruházás nôveli, a pôtlólagos tốkenövekmény termelószolgạtatásai pedig növelik a jövedelmet, és éppen ez a gazdasági növekedés lényege (Schultz, 1983: 27-28. old.)

Meylong között döntố jelentőségó osztályát: tudniillik az emberi toókébe, illetve kutatásba - akár magán-, akár állami kutatásba - való befektetést. Könyvem központi problémája az, hogy ennek a kêt. tevékenységnek a természetét és mozgásterét megvilágítsa. (Schultz, 1983, 29. old.)

'A továbbiakban az immateriális eszközök fogalmát gyakran a mérlegben nem szerepló, ün. nem anyagi eszkozzok szinonima jakent hasznaijuk. Ez az esetek tobbségeben helyes, noha neeljesen szabatos. Vannak ugyanis oly arin in aktiválásukat. Ugyanakkor vannak olyan anyaginak, materiálisnak tekintett eszközök mint a folyószámla amelyek nem ölten immaterialis eszközöket a nem anyagi eszközök szinoning használja. valamint Sveiby $(1977,2001,2003)$ munkait.

"A magyar számviteli tôrveny lehetóseget biztosít a sikeres k tatási-fejlesztési es alapitass-atszervezessi költségek aktiválásár

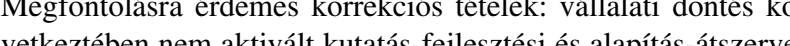
zési költségek, sikertelen kutatás-fejlesztési költségek, alapalkalmazott kutatás költségei, piackutatás, termékbevezetés, márka és piacépítés költségei, oktatási, képzési ráfordítások Korrekciót csak belsố nyilvantartás alapján tudunk végezni, az osszefoglalója is hírt adott. Lásd Chikán - Czakó, 2009: 65. old. anyagi formát. Ennek ellenére senki sem követ el hibát, ha

${ }^{10}$ E tốkeformákról részletesebben lásd Edvinsson és Malone (1997),

év végi beszámoló nem nyúit hozzá elegendó információt" - idé-

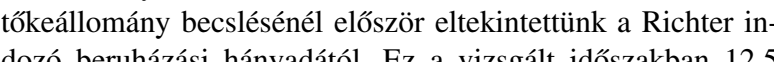

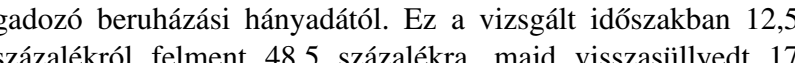
százalékra. A Richter típusú vállalatunknál ezt a hullámzást egy átlagos, 35 százalékos beruházási hányaddal helyettesítettük, és az egész idószakra âllandonak tekintettük. Ez lett a Richter típusu vall lalat $a_{1}$ beruházási hányada. A tokeảllomány alakulását ennek a beruházási hányadnak a függvényében írtuk le az eszköz mérlegek belsố tơrvennyszerưségei alapjan. A beruházási hányadselejtezések csökkentették, majd a bruttó állóeszköz-́́llományt csökkentettïk a kummulált értékcsökkenésel. Ezzel megkaptuk az a beruházási hányadhoz tartozó nettó eszközállományt. A második lépésben megemeltük a beruházási hányadot, és ennek segítségével az elốbi algoritmus alapján lényegesen magasabb nettó álloeszköz-âllományhoz jutottunk.

Az átalakítást lásd a fuggelekiben „A háromtényezős termelés

függvény átalakítása" cím alatt.
A modell eredeti ötletet́t lásd Hansen (2006)-ban. Az ott publikált modellt az eredeti ötlet üzenetének megtartásával jelentớsen átalakitottam.

Imányban bemutatott ' 4 leaf' modellt, riális tókeelemre épül; a szervezetre, a kompeten-

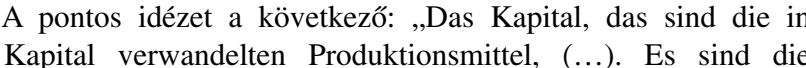
von einem bestimmten Teil der Gesellschaft monopolisierten Produktionsmittel" Karl Marx - Friedrich Engels - Werke, Band 25, „Das Kapital”, Bd. III, Siebenter Abschnitt, S. 822-839.

Persze tudjuk, hogy a tókeállomány a kitevővel együtt mozog

\section{Felhasznált irodalom}

Boda Gy. (2008): A tudástốke kialakulása és hatása a vállavány, Budapest

Boda Gy. (2010): Utemvakság (kézirat)

Chikán A. - Czakó E. (2009): Versenyben a világgal, Akadémiai Kiadó, Budapest

Edvinsson, L - Malone, M.S. (1997): Intellectual Capital, Harper Business, London

Janssen, F.B.E. (2006): Reporting the value of Intellectual Capital, The True Balance Sheet, University Maastricht, Faculty of Economics and Business Administration, Amsterdam, 6 July

Isaksson, A. (2009): The UNIDO World Productivity Database: an Overview, p. 43, UNIDO Internal Materia

Juhász P. (2004): Explanation of the Deviation between Book Value and Company Value, $(\mathrm{PhD})$ dissertation, Budapesti Corvinus University, Budapes

nómia, Osiris Kiadó, Bp. (1983). Werke, Band 25, „Das Kapika, Dietz Verlag, Berlin/DDR

\section{VEZETÉSTUDOMÁNY}

XLI. ÉVF. 2010. 7-8. SZÁM / ISSN 0133-0179 
Ónodi A. (2005): Gazdasági hozzáadott érték (EVA) mutató számítás számviteli korrekciói a magyar szabá-

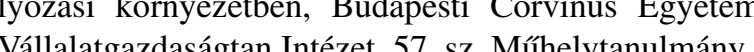
. Polanyi M. (1994): Szenelyes thas I- Il., Allantisz, Bp.

Jack Murin: Vállalatértékelés, Panem - Joh Wiley Sons, Budapest

Samuelson, P.A. (1976): Közgazdaságtan, Közgazdasági és Jogi Könyvkiadó, Budapest

(1) dasági és Jogi Könyvkiadó, Budapest iby K.E. (1977): The New Organizational Wealth, Berreth-Koehler Publishers, Inc., San Francisco

(2001): Szervezetek új gazdagsága: a menedzselt tudá. KJK Kerszôv, Budapest

F. Frm to Guide Strategy Formulation, Paper presented at ANZAM Conferen

Vurian, Hal (2004): Mikroökonómia középfokon, Egy modern megközelítés, KJK-KERSZÖV, Budapest 2007, 2002-2006, 2002-2005, letöltve február 12-én

\section{O N T E N T S}

\section{STUdies AND ARTICLES}

\section{RESZEGI, László}

\section{SZÁNTÓ, Richárd}

WIMMER, Ágnes

Violation of market norms, business decisions

and firms' efficiency

VÖRÖSMARTY, Gyöng

Efficient markets,

efficient purchasing? -

The effects of purchasing decisions on

supply markets

Business Models among changing market conditions ..

\section{KAZAI ÓNODI, Annamária}

Conflict of values and ethical dilemmas

TATRAI, Tunde

The legal and efficiency aspects of

MATOLAY, Réka

Corporate Social Responsibility:

\section{public procure \\ BODA, György}

Efficient companies,

gains and losses of efficiency ................................ 43

\section{CIKKEK ANGOL NYELVÜ ÖSSZEFOGLALÓI}

\section{RESZEGI, László}

Efficient market - efficient enterprise?

Efficient market inspires and calls into existence more efficient enterprises. Efficient taxation increases socia welfare, while weakens market efficiency and simultaneously revises the distribution of resources. Tax evasion and corruption diminish market efficiency. As calculations show, it is quite likely that the performance of both ethical and violator companies will decline, once tax evasion exists and has become remarkable. Enterprises may alter their business model as a possible answer to the environmental changes caused by tax fraud and corruption. When corruption exceeds certain level there is no solution for eliminating the efficiency setback, in addition the ethical actor may also lose its market share. As a consequence, facing a higher risk companies lose their value too. At the same time in copre dime inapprop ill shing economy and enterprises will stop being efficient.

\section{WIMMER, Ágnes}

Violation of market norms, business decisions and firms' efficiency

The decisions and the performance of business corporations are not independent of their environment. The assumed norms provide a framework for the business decisions and the existing norms affect the firms' performance. The article focuses on the efficiency consequences of the violation of the market norms. It presents the concept of corporate efficiency and its influencing factors. Then the decision makers' possible answers cy consequences are analyzed.

\section{KÖNCZÖL, Erzsébet}

Business Models among changing market conditions

Business model is a widely used term both in business connections and publications, but there are a wide range of understanding behind it. In this article first the author summarizes the concept of business model, it main building blocks and its relation to business strategy. The article focuses on the forms how companies change their business models among the recent drastic changes of their market environment. A special aspect of the changing business models is the potential violation of the market norms. The article also points out some industry-specific tendency of changing business models.

\section{KAZAI ÓNODI, Annamária}

Conflict of values and ethical dilemmas

During the decision making procedure, concentrating on shareholders' value and taking stakeholders' interest into account are not always in contradiction. Although there are some situation where the managers have to choose between the shareholders' value and the interests of another stakeholders'group. This paper shows and compares the results of an American and an Hun促 作 lations agulations and the pressure coming from the competitive economic environment are both significant factors in decision making. The managers' personal morals and ethical beliefs have been also investigated in respect of their role in decision making. The results of the two surveys were quite different.

\section{MATOLAY, Réka}

Corporate Social Responsibility: gains and losses of efficiency

Corporate Social Responsibility (CSR) based on cooperation with stakeholders promises both gains and losses of efficiency. This paper provides a summary of potential corporate bentits of responsible activitios. Characteristics and challer Chacteristics and challenges of the interpretations of and communication about CSR are in the focus of the analysis.

\section{SZÁNTÓ, Richárd}

The Risks of Fair Market Behavior

Classical articles on tax evasion usually discuss the risks of the actors who try to avoid tax compliance. However, it is rarely demonstrated that tax evasion also increases the level of risk and uncertainty for those who are still willing to pay their taxes, or in general terms 